\title{
The Contribution of Non-Canonical Gospels to the Memory of Jesus: The Gospel of Thomas and the Gospel of Peter as Test Cases*
}

\author{
JENS SCHRÖTER \\ Humboldt-Universität zu Berlin, Theologische Fakultät, Unter den Linden 6, \\ D-10099Berlin, Germany. Email: jens.schroeter@cms.hu-berlin.de
}

\begin{abstract}
This article argues that the social memory approach makes a significant contribution to the interpretation of the early gospel tradition. This approach helps to overcome an anachronistic distinction between 'canonical' and 'non-canonical' (or 'apocryphal') Gospels by highlighting the way Jesus was portrayed in various Gospels of the first and second century. Early Christian Gospels in general presuppose the post-Easter perspective on Jesus as a divine figure, but depict his activity and teaching in different ways. A closer look at the Gospel of Thomas and the Gospel of Peter demonstrates how these Gospels take up and continue perspectives which can be observed already in the earlier Gospels in their own ways. Thereby they provide glimpses of different social and theological contexts of second-century Christianity.
\end{abstract}

Keywords: memory approach, 'high Christology', early gospel tradition, secondcentury Gospels, 'canonical' and 'apocryphal' portraits of Jesus, post-Easter perspective, recreation of the Jesus story

\section{The Social Memory Approach in Jesus Studies}

The relationship of Jesus' earthly activity to its interpretation in early Christian Gospels is a perennial issue in historical-critical Jesus research. Involved are hermeneutical issues concerning the relationship of past and present in general and historical-critical interpretation of the early Jesus tradition in particular, including the question of how presentations of Jesus' earthly activity

* Paper presented at the SNTS seminar 'Memory, Narrative, and Christology in the Synoptic Gospels' at the 72nd meeting of the Studiorum Novi Testamenti Societas, 7-11 August in Pretoria. I would like to thank the participants of the seminar for a productive discussion and valuable suggestions. A special thank goes to Kelsie Rodenbiker, who made numerous invaluable suggestions to improve the English style of this article. I am also grateful to Dr Iveta Adams for her careful copy-editing and many helpful recommendations. 
and fate were influenced by Easter faith. ${ }^{1}$ Against this background, in the last two decades the term 'memory' has been applied to Jesus studies as a hermeneutical paradigm to explain how the figure Jesus of Nazareth became meaningful for his early followers and for Christian communities in post-Easter times. ${ }^{2}$ Meanwhile, a lively debate has developed over the appropriateness of the category 'memory' in historical Jesus research. ${ }^{3}$ The term is used in different ways, and it has even been contested whether the concept can contribute to Jesus studies in a meaningful way at all. ${ }^{4}$ It is therefore appropriate to begin with a definition of memory, as the term will be used in this paper in relation to and in distinction from other approaches.

From an epistemological viewpoint, 'memory' applies to the question of how the past is preserved and used in the present. Because the past itself has by definition already happened, and can be retrieved only on the basis of traces that are still available in the present, these traces - consisting of personal recollections, literary artefacts, inscriptions, coins etc. - have to be documented, critically interpreted and integrated into a historical narrative as the basis for a view of the past from the perspective of the present. This enterprise involves competence in the critical interpretation of ancient materials - e.g. reading of literary texts, inscriptions and papyri or identification of archaeological findings - as well as the creation of an image of the past that accords with such an interpretation.

'Memory' perceived in this way presupposes and makes use of historical-critical research. The 'memory approach' is therefore neither a new 'method' nor does it by itself lead to a portrait of Jesus different from those sketched by contemporary Jesus scholars. The concept of 'memory' aims instead at providing a reasonable

1 For a more recent overview on these topics, see the contributions in Jesus Handbuch (ed. J. Schröter and C. Jacobi; Tübingen: Mohr Siebeck, 2017), Part B 'Geschichte der historischkritischen Jesusforschung'.

2 I take as a reference point my book Erinnerung an Jesu Worte: Studien zur Logienüberlieferung in Markus, $Q$ und Thomas (WMANT 76; Neukirchen-Vluyn: Neukirchener, 1997). If I am not mistaken, in this book the memory approach was applied to Jesus studies for the first time in the way it will be used in this paper. For a more recent summary of my view on memory, see 'Der "erinnerte" Jesus: Erinnerung als geschichtshermeneutisches Paradigma der Jesusforschung', Jesus Handbuch (n. 1), 112-24.

3 Cf. the thematic issue 'Jesus and Memory: The Memory Approach in Current Jesus Research', EC 6/3 (2015). See also A. Kirk and T. Thatcher, eds., Memory, Tradition, and Text: Uses of the Past in Early Christianity (Semeia Studies 52; Atlanta, GA: SBL, 2005); L. T. Stuckenbruck, S. C. Barton and B. G. Wold, eds., Memory in the Bible and Antiquity (WUNT 212; Tübingen: Mohr Siebeck, 2007); A. Kirk, 'Memory Theory and Jesus Research', Handbook for the Study of the Historical Jesus, vol. I: How to Study the Historical Jesus (ed. T. Holmén and S. E. Porter; Leiden/Boston: Brill, 2011) 809-42; S. Butticaz and E. Norelli, eds., Memory and Memories in Early Christianity (WUNT 398: Tübingen: Mohr Siebeck, 2018). The next issue of the Journal for the Study of the Historical Jesus will be devoted to this topic as well.

4 Cf. e.g. P. Foster, 'Memory, Orality, and the Fourth Gospel: Three Dead-Ends in Historical Jesus Research,' JSHJ 10 (2012) 191-227. 
epistemological basis for the study of the historical Jesus and the various receptions of his person, activity and fate. Thereby the memory approach wants to create an awareness of possible shortcomings of both a predominance of the post-Easter confessions at the expense of the meaning of Jesus' pre-Easter activity on the one hand, and a 'positivistic' approach to a historical Jesus 'behind' the traces of the past on the other. Whereas the former view (the older form-critical model, developed by Rudolf Bultmann, Martin Dibelius and others) does not sufficiently take into account the impact of Jesus' earthly activity on the shaping of Christian faith outlined in early Gospels (and also in other early Christian writings), the latter view (the quest of a 'historical Jesus' in its traditional form since Reimarus) underestimates the fact that the historian must create an image of the past by using his or her 'historical imagination'. ${ }^{5}$ Images of the past are therefore based upon the knowledge of ancient sources and the values and social status of the interpreter as well as on his or her epistemological presuppositions and scholarly beliefs.

The consequences of this insight are twofold. On the one hand, it highlights the fact that the interpreter must not impose his or her own view uncritically upon the historical sources. Instead, it is indispensable to differentiate the ancient sources themselves from later perspectives on them. A (self-)critical attitude is indispensable in order to do justice to the sources of the past and not just to detect our own ideas in them. On the other hand, the interpreter makes the past accessible in his or her own time by way of excavating, translating and interpreting the historical material. That the perception of the past is restricted by the historical knowledge and the interpretative skills of the interpreter is therefore no disadvantage, but is rather the presupposition for making the past meaningful for the present. In highlighting these conditions of historical-critical interpretation, the memory approach aims at hermeneutical reflection on doing history.

'Memory' in this approach is perceived as 'social', 'collective' and 'cultural'. The first two concepts were introduced by Maurice Halbwachs, who referred to the social frameworks of individual recollections as well as to the collective dimension of the common past of a group or society. ${ }^{6}$ Jan Assmann added the category 'cultural memory' to fill in a gap in Halbwachs' theory, namely that memory can take the form of a tradition, available in stories recalling a founding past, rituals celebrating basic events of a common history, or memorials that recall certain events in history. ${ }^{7}$

5 The expression 'historical imagination' plays an important role in R. G. Collingwood's concept of history. Cf. R. G. Collingwood, The Idea of History (Oxford: Oxford University Press, 1946; rev. edn with an introduction by J. van der Dussen, 1993). By using this phrase, Collingwood did not describe historical reconstructions (or constructions) as fictions, but emphasised that 'history' is a concept in human minds, based on artefacts of the past.

6 M. Halbwachs, La mémoire collective (Paris: Presses Universitaires de France, 1950 [1939]); idem, Les cadres sociaux de la mémoire (Paris: Presses Universitaires de France, 1952 [1925]).

7 Cf. J. Assmann, Das kollektive Gedächtnis: Schrift, Erinnerung und politische Identität in frühen Hochkulturen (Munich: C. H. Beck, 1992; Engl. trans.: Cultural Memory and Early Civilization: 
The concept of memory as social, collective and cultural has to be distinguished from other usages that have also been applied to Jesus studies. Its aim is different from e.g. the analysis of individual recollections stored in the memory of human beings, and the investigation of the capacity of the human mind to preserve events in a reliable way. ${ }^{8}$ Individual memories are important for the preservation and transmission of events from the past. The social memory approach, however, interprets these memories with regard to their social conditions. In collective memory, individual recollections become part of a common perception of the past by a community or society. Although individual memories are therefore important for the formation of collective memory, they are integrated into a broader framework formed by the various recollections of a common past preserved by a social group. Individual and collective memories are therefore related to each other, although they have their distinctive characteristics. Whereas individual memories, preserved by the human mind, are vulnerable to forgetting, misperception, transience and the like, ${ }^{9}$ collective memory is shared by the members of a group, society or religious community as a common perception of a meaningful past. Collective memory is not a stable entity; rather, due to alterations and revisions, e.g. by fresh views on historical events or by the discovery of historical sources previously not known, it remains in a state of flux. The operative modes of collective memory are, however, different from those of individual memory.

In the course of time, collective memory becomes independent of individual recollections and develops into a tradition, adopted in narratives and celebrated in rituals or memorial days. As cultural memory, it serves as the framework for the basic values and beliefs of a community or a society. Cultural memory has a foundational effect, e.g. as the founding myth, basic narrative or common perspective on history of a religious group or a society. These myths or narratives can be revised and reinterpreted. Cultural memory is therefore not a fixed body of traditions, but is open to modification and correction.

Writing, Remembrance, and Political Imagination (Cambridge: Cambridge University Press, 2011)). See also A. Assmann, Der lange Schatten der Vergangenheit: Erinnerungskultur und Geschichtspolitik (Munich: C. H. Beck, 2006); eadem, 'Probleme und Chancen der Erinnerungskultur', Geschichte und Gott. XV. Europäischer Kongress für Theologie (14.-18. September 2014 in Berlin) (ed. M. Meyer-Blanck; VWGTh 44; Leipzig: Evangelische Verlagsanstalt, 2016) 173-85.

8 The memory concept was applied to Jesus studies in this way e.g. by R. A. Bauckham, Jesus and the Eyewitnesses: The Gospels as Eyewitness Testimony (Grand Rapids: Eerdmans, 2006, rev. and expanded edn $2017^{2}$ ); R. K. McIver, Memory, Jesus, and the Synoptic Gospels (Resources for Biblical Study 59; Atlanta: SBL, 2011).

9 Cf. D. L. Schacter, 'The Seven Sins of Memory: Insights from Psychology and Cognitive Neuroscience,' American Psychologist 54 (1999) 182-203. 
The social memory approach is thus interested in the meaning of the past for the identity of a community or society. Its methodological bases are the methods and tools of historical-critical research - in this case: the quest for the historical Jesus. At the same time, this approach points out that this quest can only be pursued by taking into account how the figure of Jesus was perceived and interpreted in early Christianity. Consequently, the concept of social and cultural memory does not dispense with the past in order to deal exclusively with its reception. This approach also does not analyse individual recollections or their possibilities and limitations. Instead, it aims at exploring the interrelation between the identity of a community and its common past. With regard to Jesus studies, the social memory approach therefore provides a hermeneutical framework to make plausible how the figure of Jesus is reflected in its various receptions. This perspective takes seriously insights developed in the hermeneutics of historiography, which highlight the interdependence of critical analysis of historical material and historical imagination. ${ }^{10}$ It is also dependent on the hermeneutics of Wirkungsgeschichte, especially on the insight that the historian and the historical object are always involved in a hermeneutical situation that determines the way in which the object is perceived. Historical interpretation does not take place in a 'neutral' environment. Rather, the horizons of the interpreter and the interpreted object have to merge in order to make the past meaningful for the present. ${ }^{11}$ In this way, the concept of 'memory' can also be applied effectively to Jesus studies.

\section{Memories of Jesus in Early Christianity: The Framework of the Early Jesus Tradition}

In contemporary scholarship, it is a commonplace that the reception of Jesus in early Christianity cannot be restricted to the canonical or even the Synoptic Gospels. Instead, the great variety of early gospel texts must be included in an inventory of early Christian memories of Jesus. This comprises a large number of texts of different literary characters and diverse contents, ${ }^{12}$ reflecting

10 Cf. J. G. Droysen, Outlines of the Principles of History (trans. by E. B. Andrews; Boston: Ginn \& Company, 1893; original German: Grundriss der Historik: Letzte Druckfassung, Leipzig: Veit \& Comp., 1882); Collingwood, Idea of History (n. 5).

11 Cf. H. G. Gadamer, Wahrheit und Methode (reprint of the 6th rev. edn, Tübingen: Mohr Siebeck, 1999) 305-12.

12 For the so-called 'apocryphal Gospels', cf. the following collections: J. K. Elliott, The Apocryphal New Testament: A Collection of Apocryphal Christian Literature in an English Translation (Oxford: Clarendon, 1993, repr. 2009); B. D. Ehrman and Z. Plese, The Apocryphal Gospels: Texts and Translations (New York/Oxford: Oxford University Press, 2011); C. Markschies and J. Schröter, eds., Antike christliche Apokryphen in deutscher Übersetzung, vol. I: Evangelien und Verwandtes (in zwei Teilbänden) (Tübingen: Mohr 
a great variety of perspectives on Jesus, his relationship to God and the meaning of the Jewish Scriptures for the interpretation of Jesus' activity and fate. The categorisation of these texts as 'accepted', 'rejected' and 'contested' writings, ${ }^{13}$ or as 'canonical' and 'apocryphal' books, ${ }^{14}$ developed in the course of the second to the fourth century, is due to a certain evaluation of these writings from the perspective of what became the normative collection of Gospels in the church.

From a perspective of social and collective memory, this raises the question of the relationship between various perspectives on Jesus presented in early Gospels. In other words: is there a difference between such portraits of Jesus that later achieved 'canonical' status and others that were rejected as 'apocryphal', or was such a distinction only developed by Christian theologians whereas these Gospels existed side by side without any difference in meaning for early Christian communities, at least until the end of the second century $?^{15}$ In the following remarks, this question will be addressed, beginning with a look at the general interpretative framework of the early Jesus tradition and its development in second-century Gospels. Concerning the latter, I will concentrate on the Gospel of Thomas and the Gospel of Peter and their place within the development of early memories of Jesus.

Remarkably, the earliest Christian texts are already concentrated on Jesus' salvific death and his resurrection and exaltation, sometimes also his sending by God and his pre-existence. In many cases these themes are cited in Pauline and Deutero-Pauline letters. According to a widespread opinion, several passages (e.g. 1 Cor 15.3-5; Phil 2.6-11; Col 1.15-20) were composed as confessions or hymns independently of the literary contexts in which they now appear. ${ }^{16}$ Traces of language shaped by early Christian phrases or formulae can also be detected in texts such as Rom 4.25, 1 Tim 3.16, 1 Pet 3.18 and Eph 1.20-3, as well as in some passages in the Acts of the Apostles, the Apocalypse of John

Siebeck, 2012); T. Burke and B. Landau, eds., New Testament Apocrypha: More Noncanonical Scriptures, vol. I (Grand Rapids: Eerdmans, 2016). See also the proceedings of the Colloquium Biblicum Lovaniense 2001: J. Schröter, ed., The Apocryphal Gospels within the Context of Early Christian Theology (BETL 260; Leuven: Peeters, 2013).

13 Cf. Eusebius, Hist. eccl. 3.25.1-6.

14 Cf. Athanasius, Ep. fest. 39.

15 For a recent approach to describing the relationship of canonical and non-canonical Gospels, see F. Watson, Gospel Writing: A Canonical Perspective (Grand Rapids/Cambridge: Eerdmans, 2013). Cf. also F. Watson and S. Parkhouse, eds., Connecting Gospels: Beyond the Canonical/ Non-Canonical Divide (Oxford: Oxford University Press, 2018).

16 Cf. R. Deichgräber, Gotteshymnus und Christushymnus in der frühen Christenheit: Untersuchungen zu Form, Sprache und Stil der frühchristlichen Hymnen (SUNT 5; Göttingen: Vandenhoeck and Ruprecht, 1967); K. Wengst, Christologische Formeln und Lieder des Urchristentums (StNT 7; Gütersloh: Gütersloher Verlagshaus Gerd Mohn, 1972); M. Hengel, 'Das Christuslied im frühesten Gottesdienst', idem, Studien zur Christologie: Kleine Schriften, vol. Iv (WUNT 201; Tübingen: Mohr Siebeck, 2006) 205-58. 
and the letters of Ignatius. The 'high Christology' articulated in these texts shows that devotion to the resurrected and exalted Lord Jesus Christ was a characteristic feature of the Christian movement from its very beginning. ${ }^{17}$ Details about the activity of the earthly Jesus, by contrast, are only of minor importance in these texts.

Regardless of the different portrayals of Jesus, his exclusive relationship with God and his extraordinary authority as God's final envoy are also presupposed in the depictions of his earthly activity in early Christian Gospels. Even if the far-reaching perspective of early Christian hymns or confessions, encompassing Jesus' pre-existence, his appearance on earth and his resurrection and exaltation, occurs only in some of these writings - e.g. in the Gospel of John, the Apocryphon of John or the so-called Gospel of Truth - the conviction of his unique status determines the description of his earthly activity from its very beginning. ${ }^{18}$

Accordingly, in contrast to modern views on Jesus, which usually try to find the humanity of Jesus behind the pre-existent, resurrected and exalted Lord, early Christian Gospels emphasise his exclusive origin and exceptional power during his earthly activity. This applies to canonical as well as to non-canonical texts, although, as we will see, non-canonical Gospels often accentuate Jesus' relationship with the upper world, the extraordinary circumstances of his birth or his exceptional wisdom in a distinctive manner. Whether this characteristic also influenced the distinction between accepted and rejected Gospels remains uncertain. In any case, early Christian theologians do not reject these Gospels because of their emphasis on Jesus' divinity at the expense of his earthly existence. Rather, the Christian memory of Jesus was from its very beginning characterised by the conviction that he appeared on earth as God's son, empowered by God's Spirit and acting on God's authority. As a consequence, the relationship between Jesus' divine origin and his earthly existence was a crucial issue in early Gospels from the very beginning.

In the Gospel of Mark, in all probability the oldest narrative about Jesus, he is introduced with an account of the bestowal of God's Spirit and his acknowledgement as the beloved Son of God by the heavenly voice (1.9-11) that also speaks at Jesus' transfiguration (9.7). Towards the end of the narrative, the young man in the empty tomb proclaims the resurrection of Jesus in the form of an early Christian confession: 'You are looking for Jesus, the Nazarene, the crucified; he

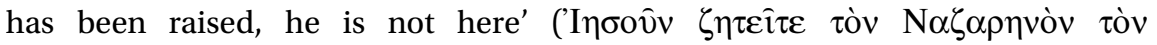

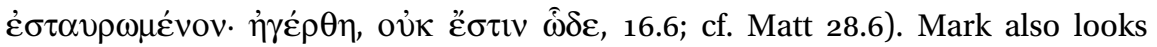

17 Cf. W. Kramer, Christos, Kyrios, Gottessohn: Untersuchungen zu Gebrauch und Bedeutung der christologischen Bezeichnungen bei Paulus und den vorpaulinischen Gemeinden (AThANT; Zurich: Zwingli, 1963); L. W. Hurtado, Lord Jesus Christ: Devotion to Jesus in Earliest Christianity (Grand Rapids/Cambridge: Eerdmans, 2003) 98-153 (on christological language and themes in early Pauline Christology).

18 Cf. Hurtado, Lord Jesus Christ (n. 17), 262-74. 
forward to Jesus' return as Son of man at the last judgement (Mark 8.38; 13.26-7; 14.62). In this authority Jesus acts on earth as God's representative who even claims for himself the ability to forgive sins, ${ }^{19}$ which is contested by the scribes who refer to the Shema (Deut 6.4) as proof that God alone is entitled to forgive sins. $^{20}$ The description of Jesus' earthly activity is therefore embedded in a broader framework with affinities to the confession formulae mentioned above. ${ }^{21}$ In Mark this view of Jesus is for the first time combined with an account of his earthly activity.

Within the narrative itself, it is especially the miracle stories that emphasise Jesus' extraordinary status. ${ }^{22}$ The account of Jesus walking on the Sea ${ }^{23}$ and making himself known to the disciples ${ }^{24}$ can be characterised as an 'epiphanic story'. Through the references to God's self-introduction in biblical texts ${ }^{25}$ Jesus is depicted as God's agent. A closely related story is the account of the stilling of the storm (Mark 4.35-41), ending with a reference to the disciples' fear in the face of the extraordinary power of Jesus whom even the wind and the sea obey. In the Matthean parallels ${ }^{26}$ the 'epiphanic' elements are emphasised even more strongly: the disciples in the boat and Peter walking on the Sea are modelled after the Christian community praying to the exalted Lord Jesus for salvation

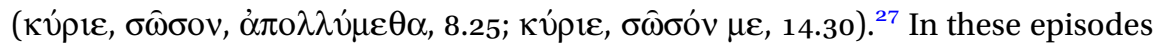
Jesus' earthly activity is therefore interpreted against the background of the confession that he is the resurrected and exalted Son of God acting on earth with divine authority.

Other features of first-century Gospels corroborate this view on Jesus. The birth narratives in the Gospels of Matthew and Luke highlight the extraordinary circumstances of Jesus' conception, pushing his origin back even into the time

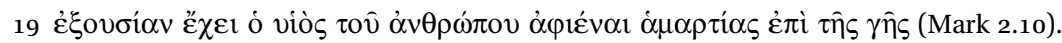

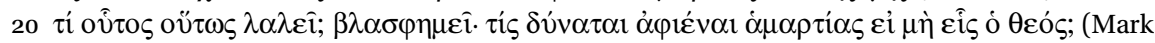
2.7).

21 Although it is disputed whether the Gospel of Mark presupposes Jesus' pre-existence, there are at least some features pointing to Jesus' sending by God, e.g. the mixed quotation from Scripture in 1.2-3, where Jesus is addressed by God himself as his representative.

22 The place of the miracle stories within Mark's overall depiction of Jesus, especially their relationship to the passion events, has been the subject of intense scholarly debate. Without going into detail here, it can be stated that the mighty deeds performed by Jesus in Mark's Gospel serve as descriptions of his extraordinary power bestowed upon him at baptism. These deeds are therefore signs of the God's reign dawning in Jesus' activity.

23 Mark 6.45-52. For cultural contexts of this account, see A. Y. Collins, Mark: A Commentary (Hermeneia; Minneapolis: Fortress, 2007) 328-33.

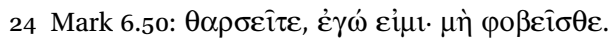

25 Cf. Exod 3.14; Deut 32.39; Isa 41.4; 43.10-11; 45.18-19; 48.12; see also John 4.26; 8.28; 9.9; $13.19 ; 18.6$.

26 Matt 14.22-33; 8.23-7. Matt 14.30 alludes to Ps $68.2-3$, 15 LXX.

27 Cf. U. Luz, Das Evangelium nach Matthäus (Mt 8-17) (EKK ı/2; Zürich/Braunschweig: Benziger/Neukirchen-Vluyn: Neukirchener, 1990) 27-30, 409. 
before his birth. The Gospel of John begins with an account of the pre-existent $\lambda$ ó $\gamma$ o $\varsigma$ who has divine quality and is called $\theta \varepsilon$ ó $\varsigma(1.1)$. The post-Easter perspective is emphasised by the references to Jesus' glory visible in the incarnated Logos (1.14) as well as to his resurrection and glorification, which enabled his disciples to grasp the meaning of his earthly career in its full sense. ${ }^{28}$ The extensive farewell scene in John 13-17 elaborates the post-Easter perspective by pointing out that a comprehensive view of Jesus as the Son of God who was sent from above is only possible after his return to the heavenly Father. ${ }^{29}$

The appearance stories in the Gospels of Matthew, Luke and John serve as an important link between the post-Easter remembrances of Jesus and his earthly activity. These accounts refer to the proclamation of Jesus' teaching to all peoples and to baptism (Matt 28.19), to the renewal of the breaking of the bread with the resurrected Jesus (Luke 24.30), and to the commission of the disciples and the pouring out of the Holy Spirit (John 20.21-2). These accounts therefore emphasise the continuity between the earthly Jesus and the resurrected one. The disciples on their way to Emmaus (Luke 24.13-35) and Mary Magdalene (John 20.11-18) are at first not able to identify Jesus because he has already entered the heavenly glory (Luke 24.26) or is on his way back to the Father (John 20.17). The breaking of bread by the resurrected Jesus and his address to Mary, however, highlight that the resurrected Jesus is the same as the preEaster, crucified one. The appearances of the resurrected Jesus therefore serve as narrative connections between Jesus' pre-Easter activity and his post-Easter perception. This becomes evident also from a look at the textual transmission of the Gospels of John and Mark as well as at second-century Gospels.

The addition of chapter 21 to the Gospel of John expounds the post-Easter perspective of this Gospel in a specific way by narrating appearances of the resurrected Jesus to the disciples and to Peter after the 'first closure' of the book in 20.30-1..$^{30}$ Chapter 21 is closely related to the previous narrative in language and style, although there are some peculiarities, e.g. several hapax legomena, ${ }^{31}$ the remark that Nathanël comes from Cana and the reference to the sons of Zebedee (both in 21.2), who are not previously mentioned in the Gospel. ${ }^{32}$ By resuming the appearance stories of chapter 20 , the text focuses on the post-

28 Cf. John 2.22; 12.16.

29 Cf. C. Dietzfelbinger, Der Abschied des Kommenden: Eine Auslegung der johanneischen Abschiedsreden (WUNT 95; Tübingen: Mohr Siebeck, 1997).

30 Cf. J. Zumstein, 'Die Endredaktion des Johannesevangeliums (am Beispiel von Kapitel 21)', idem, Kreative Erinnerung: Relecture und Auslegung im Johannesevangelium (AThANT 84; Zurich: Theologischer Verlag, 2004 ${ }^{2}$ 291-315.

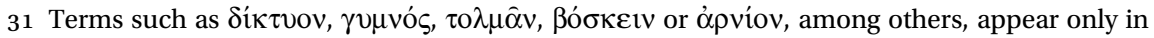
chapter 21 of John's Gospel.

32 Cf. T. Heckel, Vom Evangelium des Markus zum viergestaltigen Evangelium (WUNT 120; Tübingen: Mohr Siebeck, 1999) 128-90. 
Easter situation of discipleship, the communal meal with the resurrected Jesus, and the role of the beloved disciple as well as Peter as the 'shepherd' of the community. John 21 therefore links the Gospel of John to other Jesus traditions, especially in the renewal of commensality with the resurrected Jesus and the role of Peter as the leading figure of the disciples in post-Easter times. ${ }^{33}$

The so-called 'Longer Ending of Mark' belongs to the same development of the early gospel tradition. ${ }^{34}$ In contrast to John 21 , however, this text has no inherent relationship to Mark's Gospel. In all probability, it originated independently as an account of appearances of the risen Jesus to his disciples, concluding with his ascension. The text has close relationships to traditions about appearances of the resurrected Jesus and his ascension in the Gospels of Matthew, Luke and John. It was probably added to Mark's Gospel in the first half of the second century, filling in a 'gap' in Mark's story of Jesus whose enigmatic ending was a concern already at an early stage. ${ }^{35}$

The early gospel tradition therefore emphasises Jesus' exclusive relationship with God, sometimes even his pre-existence, and the extraordinary circumstances of his birth as the overall framework of his earthly activity. The narratives relate his pre-Easter activity to post-Easter times, making it accessible for the Christian community on the basis of the post-Easter confession. At the turn of the first to the second century this perspective was elaborated further in accounts of encounters between the resurrected Jesus and his disciples. The appearance stories of the early Gospels as well as passages added to them at a later stage thereby serve as connections between Jesus' earthly activity and its post-Easter reception.

In second-century Gospels, the presentation of Jesus as an extraordinary figure is further elaborated. ${ }^{36}$ The so-called 'Protevangelium of James' depicts the miraculous circumstances of the births of Mary and Jesus by taking up traditions

33 Rudolf Schnackenburg rightly points out that chapter 21 is not just an addendum ('Nachtrag') or an appendix ('Anhang') or epilogue, but an editorial closure which provides a key for the readers of that time to understand the whole Gospel ('redaktionelles Schlußkapitel mit einer sinnerschließenden Funktion für die damaligen kirchlichen Leser'). See idem, Das Johannesevangelium. Dritter Teil: Kommentar zu Kapitel 13-21 (HThK iv/3; Freiburg et al.: Herder, 1975) 409.

34 Cf. J. A. Kelhoffer, Miracle and Mission: The Authentication of Missionaries and their Message in the Longer Ending of Mark (WUNT II/112; Tübingen: Mohr Siebeck, 2000).

35 The Longer Ending of Mark was already known to Irenaeus, cf. Haer. 3.10.6, quoting Mark 16.19. Sometimes it is assumed that it is also presupposed in the Epistula Apostolorum.

36 In spite of some claims to the contrary, in my perspective it remains most likely that the noncanonical Gospels originated from the second half of the second century onwards. Texts such as ProtJas, Gos. Thom., Gos. Pet., Gos. Mary, Gos. Egerton and some others in all probability originated in the later second or early third century, not in the first, but also not in the fourth or fifth century. I cannot discuss this question here in detail, but there are sufficient reasons for this assumption. 
that also appear in the infancy stories of Matthew and Luke. ${ }^{37}$ The Gospel of Peter stresses the extraordinary events of Jesus' resurrection by narrating his exit from the tomb supported by two heavenly figures and followed by the cross. ${ }^{38}$ In the Gospel of Thomas Jesus' teaching is presented as 'hidden words of the living Jesus' written down by Didymus Judas Thomas (cf. the incipit). Jesus is depicted as the revealer of a heavenly wisdom who appeared in the midst of the world and taught about the way to the Kingdom of the Father. In relation to Platonic anthropology, Jesus teaches about the heavenly origin of human beings to which they are to return. ${ }^{39}$ The Gospel of Mary belongs to those Gospels that use traditions of appearances of the resurrected Jesus as their narrative setting for his postEaster teaching. ${ }^{40}$ It takes as its starting point a post-Easter encounter between Jesus and his disciples to depict his teaching about the dissolution of matter and soul and the ascent of the soul through the realms of the seven powers. The extant text begins in the middle of a dialogue about the dissolution of matter and soul. At a later stage, Mary reports a vision about the ascent of the soul to the upper world. The origin of the human being, his/her relationship to the upper world and the role of Jesus as the mediator between the upper world and the material world therefore prove to be important issues in the Gospel of Mary. $^{41}$

The non-canonical Gospels therefore take up important aspects of the earlier Gospels and elaborate them in specific ways. In at least some of these Gospels the meaning of the earthly Jesus is diminished as the focus switches to the extraordinary circumstances of his birth or his resurrection. The activity and teaching of the pre-Easter Jesus can even be replaced entirely by an instruction from the resurrected Jesus about the upper world as the origin and destiny of the human being. Against this background, in the following remarks the relationship of Jesus' extraordinary status to his earthly activity as it is presented in secondcentury Gospels will be analysed more closely by way of two examples.

37 Cf. S. Pellegrini, 'Das Protevangelium des Jakobus', Antike christliche Apokryphen, I.903-29;

L. C. Vuong, Gender and Purity in the Protevangelium of James (WUNT II/358; Tübingen: Mohr Siebeck, 2013); E. M. Vanden Eykel, 'But their Faces Were All Looking up': Author and Reader in the Protevangelium of James (London et al.: Bloomsbury T\&T Clark, 2016).

38 Cf. J. J. Johnston, The Resurrection of Jesus in the Gospel of Peter: A Tradition-Historical Study of the Akhmîm Gospel Fragment (London: Bloomsbury T\&T Clark, 2016).

39 Cf. S. J. Patterson, 'Jesus meets Plato: The Theology of the Gospel of Thomas and Middle Platonism', idem, The Gospel of Thomas and Christian Origins: Essays on the Fifth Gospel (NHMS 84, Leiden/Boston: Brill, 2013) 33-59; idem, 'Platonism and the Apocryphal Origins of Immortality in the Christian Imagination or Why do Christians Have Souls that Go to Heaven?', ibid., 61-91.

40 Cf. J. Hartenstein, Die zweite Lehre: Erscheinungen des Auferstandenen als Rahmenerzählungen frühchristlicher Dialoge (TU 146; Berlin: Akademie Verlag, 2000).

41 Cf. K. L. King, The Gospel of Mary: Jesus and the First Woman Apostle (Santa Rosa, CA: Polebridge, 2003), esp. 37-81. 


\section{Perspectives on Jesus' Earthly Activity in Second-Century Gospels: The 'Gospel according to Thomas' and the 'Gospel according to Peter' as Test Cases}

The Gospels of the first century are narratives about Jesus' public activity in Galilee, Judea and Jerusalem, as well as the surrounding regions: the Decapolis, the region around Caesarea Philippi, and the coastal region of Tyre and Sidon. Even if these accounts were preceded by sayings collections or miracle catenae in written form (which is possible, but hard to prove with certainty), the first tangible format of the gospel traditions is the biographical narrative. The hypothetical sayings source Q corroborates this assumption since, as far as it can be recognised from Matthew and Luke, it consisted in a collection of speeches of Jesus combined with narrative episodes such as the temptation story, the Beelzebul controversy, perhaps a healing story (the centurion's son, Matt 8.1-13/Luke 7.1-10) and an account of Jesus' baptism. Thus, in the early Jesus tradition not only is the content of his teaching preserved, but also a specific setting, containing the locations of his activity, the political and social situation in Galilee, names and occupations of his followers, characterisations of his adversaries, information about his home town and his family, and, in some cases, the names of healed persons. In the early Gospels, these details are integrated into narrative accounts written in later political and social circumstances. Moreover, Jesus' activity is interpreted through quotations from Scripture and on the basis of post-Easter confessions. Nevertheless, the narrative character of the early Jesus tradition reveals a 'biographical' interest in the figure of Jesus that exceeds the scant information of early confessional formulae and the references to the 'words of the Lord' in Paul's letters.

The narrative presentation of Jesus' activity in its Galilean and Judean setting also serves as the basis for putting the 'historical Jesus' in his cultural, social and religious context. ${ }^{42}$ The early Gospels depict Jesus acting in a Jewish environment and as himself deeply influenced by Jewish traditions. This emphasis, which is particularly characteristic of the Gospels of Matthew and Luke, is corroborated by archaeological excavations in Galilee since the 1970s, which have shown that the Galilee of Jesus' time was a Jewish territory with close relationships to Judea and Jerusalem. ${ }^{43}$ The gospel writers, by contrast, are influenced by a

42 Cf. e.g. S. Freyne, Jesus, a Jewish Galilean: A New Reading of the Jesus Story (London/New York: T\&T Clark International, 2004).

43 Cf. J. L. Reed, Archaeology and the Galilean Jesus: A Re-examination of the Evidence (Harrisburg: Trinity International, 2000); M. A. Chancey, Greco-Roman Culture and the Galilee of Jesus (SNTSMS 134; Cambridge: Cambridge University Press, 2005); D. A. Fiensy and J. R. Strange, eds., Galilee in the Late Second Temple and Mishnaic Periods, vol. I: Life, Culture, and Society (Minneapolis: Fortress, 2014); vol. II: The Archaeological Record from Cities, Towns, and Villages (Minneapolis: Fortress, 2015). 
post-70 image of Judaism as well as by the conflicts between Christ groups and Jews who rejected Jesus and his followers. However, even if Jewish groups and individuals are often stereotyped and the hostile attitude of the Jews against the Christians is interpreted through quotations from Scripture, the Synoptic tradition is aware of the Jewish character of Galilee in Jesus' own time in distinction from the surrounding regions of the Decapolis and the region of Tyre and Sidon.

In the Synoptic tradition, Jesus is therefore remembered as a Galilean Jew acting primarily in Israel and among the Jewish people. ${ }^{44}$ This narrative framework is altered considerably in the later gospel tradition. Already in the Gospel of John the narrative setting of Jesus' activity gains a symbolic meaning by depicting the кó $\sigma \mu \varsigma$ and the upper world as two realms brought into relation with each other by the incarnate $\lambda$ óyos. Although there can be no doubt that the Gospel of John regards the world as God's creation and not as a hostile place (cf. esp. 3:16), there is a sharp contrast between this world and God's reign, below and above, death and eternal life. The Johannine narrative framework therefore underscores Jesus' origin from above and interprets the activity of the earthly Jesus from this perspective. ${ }^{45}$ This tendency is further elaborated in other Gospels of the second and third centuries.

\subsection{The 'Gospel according to Thomas'}

Of special interest in this regard is the Gospel of Thomas (hereafter in this section Gos. Thom.). On the basis of the Greek fragments (esp. P.Oxy. 654 and P. Oxy. 1$)^{46}$ and the remarks of Origen and Hippolytus ${ }^{47}$ the origin of this Gospel can be dated to the second half of the second century, whereas the Coptic translation probably did not originate before the third or fourth century. ${ }^{48}$ Gos. Thom.

44 Cf. S. Freyne, 'Jesus and the Urban Culture of Galilee', idem, Galilee and Gospel: Collected Essays (WUNT 125; Tübingen: Mohr Siebeck, 2000) 183-207.

45 Cf. D. M. Smith, 'Jesus Tradition in the Gospel of John', Handbook for the Study of the Historical Jesus, vol. III: The Historical Jesus (ed. T. Holmén and S. E. Porter; Leiden/Boston: Brill, 2011) 1997-2039.

46 For a description of the fragments, see L. W. Hurtado, 'The Greek Fragments of the Gospel of Thomas as Artefacts: Papyrological Observations on Papyrus Oxyrhynchus 1, Papyrus Oxyrhynchus 654 and Papyrus Oxyrhynchus 655', Das Thomasevangelium: Entstehung Rezeption - Theologie (ed. J. Frey, E. E. Popkes and J. Schröter with the collaboration of C. Jacobi; BZNW 157, Berlin/New York: de Gruyter, 2008) 19-32; reprinted in L. W. Hurtado, Texts and Artefacts: Selected Essays on Textual Criticism and Early Christian Manuscripts (LNTS 584; London/New York: Bloomsbury T\&T Clark, 2018) 167-81. It should be noted, however, that P.Oxy. 655, although often referred to as a fragment of Gos. Thom. in Greek, is a more complicated case. Regarding the differences between the Greek and Coptic texts, it is rather unlikely that this fragment should be regarded as belonging to a Greek version of Gos. Thom.

47 Origen, Hom. Luc. 1.2; Hippol. Haer. 5.7.20.

48 The study of W. Eisele, Welcher Thomas? Studien zur Text- und Überlieferungsgeschichte des Thomasevangeliums (WUNT 259; Tübingen: Mohr Siebeck, 2010), is devoted to the relationship of the Coptic and the Greek text of Gos. Thom. 
therefore provides a glimpse of the interpretation of the Jesus tradition from a second-century perspective, even if perhaps from the margin of the reception of Jesus in early Christianity. ${ }^{49}$ It is thus reasonable to incorporate it into a description of the development of the early gospel tradition. ${ }^{50}$

Although Gos. Thom. does not contain detailed descriptions of the milieu of Jesus' activity, the geographical and personal setting of earlier narratives is clearly presupposed. There are references to places (saying 60: a Samaritan on his way to Judea), disciples (sayings 13: Simon Peter, Matthew, Thomas; 21 and 114: Mary; 61: Salome), Jesus' family (sayings 99: Jesus' brothers and his mother; 12: James the Just) as well as to Jewish groups (sayings 39 and 102: the Pharisees (and scribes)) or the Jews in general (saying 43). Gos. Thom. refers critically to Jewish customs such as fasting, prayer, alms-giving, food laws, Sabbath observance and circumcision (sayings $6 ; 14 ; 27$; 53) and it mentions the resurrection of the dead and the prophets of Israel in a critical way (sayings 51 and 52). Even if Gos. Thom. does not describe Jesus' Galilean or Judean context in more detail and does not contain a healing story, a controversy with his adversaries or an account of his passion and death, his earthly appearance 'in flesh' (saying 28) is clearly presupposed as the context of his 'hidden words' addressed to his followers. It should also be noted that, contrary to what is often maintained, the stereotypical introduction 'Jesus says/said' does not make Gos. Thom. a 'sayings collection'. In sayings collections, e.g. the Sentences of Sextus or the Teachings of Silvanus, the authority of the speaker is introduced at the beginning of the whole collection, but not repeated time and again within the text itself. ${ }^{51}$ In Gos. Thom., by contrast, the introduction of each individual unit points to the fact that Jesus spoke these words in certain situations. A narrative setting, even if it is not developed in more detail, is not entirely absent. ${ }^{52}$ Instead, Gos. Thom. points to some basic information about the situation of Jesus' earthly ministry as well as to the disciples as the addressees of his teaching, whereas the Jews (or the Pharisees and scribes) are characterised as those who do not understand and hinder others from perceiving the meaning of Jesus' 'hidden words'. The aim of this presentation is to emphasise that Jesus' teaching is not accessible to everyone,

49 Cf. A.-M. Luijendijk, 'Reading the Gospel of Thomas in the Third Century: Three Oxyrhynchus Papyri and Origen's Homilies', Reading New Testament Papyri in Context - Lire les papyrus du Nouveau Testament dans leur contexte (ed. C. Clivaz and J. Zumstein; BETL 242, Leuven: Peeters, 2011) 241-67.

50 For a comprehensive treatment of the aspects related to the place of Gos. Thom. within early Christian literature, see S. Gathercole, The Gospel of Thomas: Introduction and Commentary (TENTS 11; Leiden/Boston: Brill, 2014) 3-184.

51 This is different in the Pirke Aboth, where the sayings are ascribed to various rabbis who are identified at the beginning of the individual sections.

52 Cf. K. Schwarz, 'Der "lebendige Jesus" im Thomasevangelium', Christ of the Sacred Stories (ed. P. Dragutinovic et al.; WUNT II/453; Tübingen 2017) 223-46. 
but can be comprehended only with special knowledge. The addressees of this teaching are not Christian communities, but rather the solitary ones and the elect (sayings $16 ; 49 ; 50 ; 75$ ) who have dispensed with Judaism, look critically at Jewish customs and live according to Jesus' teaching, which is depicted as a way of life, in solitude and radical asceticism, that leads to salvation. Accordingly, the world is called a 'corpse' or a 'body' (sayings 56; 80) and the addressees are urged to abstain from the world (saayings $27 ; 110$ ).

Gos. Thom. does not contain a mythology about the upper world, nor does it present Jesus as a heavenly redeemer who would have entered this world without becoming a 'real' human being. The origin of human beings is described as the 'Kingdom of the Father' from which they came and to which they shall return (saying 49). Adam is portrayed as originating from a great power and a great wealth, which is undoubtedly a positive depiction of God as the creator of the human race (saying 85). Gos. Thom. can therefore be regarded as an interpretation of the Jesus tradition which emphasises the difference between the heavenly Kingdom and the earthly realm more strongly than previous Gospels, including the Gospel of John. Its anthropology is influenced by the Platonic idea that human beings have heavenly counterparts or images that came into being before human beings themselves. ${ }^{53}$ Gos. Thom. therefore elaborates tendencies that can be observed already in the earlier gospel tradition. It is not a 'gnostic' gospel, although it may have been used by 'gnostic' groups. The most striking difference from previous Gospels is that, in Gos. Thom., Jesus' teaching is significantly more detached from a concrete social and religious milieu. This opens up the possibility of replacing the narrative framework of the earlier Gospels by the introduction of new contents, e.g. a different anthropology and a modified description of the relationship to Jewish customs. Nevertheless, Gos. Thom. can be regarded as a specific form of the memory of Jesus. It takes up traditions from earlier Gospels and incorporates them into a new framework, which is related to philosophical interpretations of the Christian message. Gos. Thom. can therefore be regarded as an innovative reinterpretation of earlier Jesus traditions presenting them as a teaching for the solitary and elect who will enter the 'Kingdom of the Father'.

\subsection{The 'Gospel according to Peter'}

My second example is the Gospel of Peter (hereafter in this section Gos. Peter). ${ }^{54}$ As is well known, this Gospel is mainly attested by the Akhmîm codex, probably from the sixth or seventh century. If P.Oxy. 2949 from the second or

53 Cf. I. Miroshnikov, 'The Gospel of Thomas and Plato: A Study of the Impact of Platonism on the "Fifth Gospel"' (Academic diss.; Helsinki, 2016).

54 For a more recent comprehensive interpretation, see P. Foster, The Gospel of Peter: Introduction, Critical Edition and Commentary (TENT 4; Leiden/Boston: Brill, 2010). Cf. also T. J. Kraus and T. Nicklas, eds., Das Petrusevangelium und die Petrusapokalypse: Die 
third century was a fragment of Gos. Peter as well - which is possible, but not undisputed - an origin in the second century would be confirmed by the manuscript evidence. Other fragments are even more uncertain candidates as witnesses for Gos. Peter. ${ }^{55}$ However, there are references to a 'Gospel according to Peter' in early Christian literature which allow for a date of this Gospel in the second century. The most important of these is the letter of Serapion, preserved by Eusebius, which contains some information about the bishop's view of this Gospel. ${ }^{56}$

The interpretation of a second-century Gospel which is attested in extant form only in a sixth- or seventh-century manuscript is burdened with numerous ambiguities and uncertainties, e.g. concerning possible modifications and elaborations of the manuscript in the course of its transmission. In the case of the Akhmîm fragment it also remains an open question whether it contained an account of Jesus' earthly activity before the story of his passion, crucifixion and resurrection. On the basis of the available evidence, questions such as these can be answered only tentatively, if at all. The following observations are therefore subject to reservation.

Unlike Gos. Thom., Gos. Peter provides a narrative presentation of Jesus' activity, which, as far as the preserved part of the Akhmîm text allows us to judge, consists of the events related to his passion, crucifixion and resurrection. The relationship to earlier Gospels makes it likely that Gos. Peter builds on an already developed tradition of the passion story. ${ }^{57}$ However, compared to earlier versions, the historical circumstances are described in a rather imprecise way. At the beginning of the fragment, 'King Herod' is introduced, who, as the text continues, plays a prominent role at the trial of Jesus $(1.2 ; 2.5)$. In this remark, which only makes sense as a reference to Antipas (and is perhaps taken obliquely from Luke's Gospel), the designation 'king' ( $\beta \alpha \sigma \imath \lambda \varepsilon v$ $\varsigma$ ) is evidently mistaken. Likewise, in the vague reference to 'his [i.e. Herod's] judges' (1.1) it is not clear who these judges are. It is also Herod who gives the command to take Jesus and crucify him (1.2). Afterwards, Pilate must ask Herod for permission to bury Jesus' body (2.4). Obviously, the author thinks of

griechischen Fragmente mit deutscher und englischer Übersetzung (GCS NF 11, Neutestamentliche Apokryphen I; Berlin/New York: de Gruyter, 2004).

55 Cf. D. Lührmann, “Petrus, der Heilige, der Evangelist, verehren laßt uns ihn”: Neue Funde und Wiederentdeckungen zum Petrusevangelium', idem, Die apokryph gewordenen Evangelien: Studien zu neuen Texten und neuen Fragmente (NovTSup 112; Leiden/Boston: Brill, 2004) 55-104.

56 Eusebius, Hist. eccl. 6.12.3-6.

57 Different models to describe this relationship are discussed by P. Augustin, Die Juden im Petrusevangelium: Narratologische Analyse und theologiegeschichtliche Kontextualisierung (BZNW 214; Berlin/Boston: de Gruyter, 2015) 57-109. 
Herod as the main authority at the trial of Jesus, which in an historical regard is, of course, inaccurate. At a later point, the centurion Petronius and the soldiers are mentioned. They appear on the scene because the Jews have asked Pilate to give them soldiers as guards of Jesus' tomb to prevent his disciples from stealing his body and the crowd from coming to believe that he was risen from the dead and, in response, doing evil to the Jews (8.29-30).

This depiction is related to another striking feature of Gos. Peter, namely the image of the Jews. ${ }^{58}$ They are referred to in a general way as 'the Jews', but also in more detailed lists as 'the Jews and the elders and the priests' (7.25) or 'the scribes and Pharisees and elders' (8.28). Whereas the former listing is somewhat strange in mentioning the elders and priests besides the general reference to 'the Jews', the latter one may be explained as a listing of Jewish groups which are mentioned in the context of the passion events also in previous Gospels, especially Matthew, ${ }^{59}$ although not exactly in the way they appear in Gos. Peter. The references to Jewish groups therefore point to the tendency to give a comprehensive image of the Jews as responsible for the death of Jesus, with special emphasis on the Jewish authorities who played a prominent role in the passion events. At the same time, however, these references demonstrate that the author is not familiar with the essential characteristics of the Jewish groups and authorities, but mentions them in a general and ambiguous way.

This observation is supported by the negative image of the Jews, who are described as primarily responsible for Jesus' crucifixion. Right at the beginning of the preserved text, Herod delivers Jesus to the people, who take him, push him and mock him by clothing him in a purple robe and putting a crown of thorns on his head (3.6-9). In this scene, it becomes obvious that the author does not differentiate between the role of the Roman soldiers and that of the Jews in the passion events.

At several points the author refers to Jewish traditions. Although there is only one explicit quotation, which occurs twice, ${ }^{60}$ the fragment contains numerous allusions to Jewish Scriptures. These include the designations 'Son of God' and 'King of Israel' which are applied to Jesus, as well as details of the mocking scene and the crucifixion such as the silence of Jesus, the division of his garments and the command not to break Jesus' legs. These features also occur in the other versions of the passion story as a scriptural background to the narrated events.

58 Cf. Augustin, Juden (n. 57); T. Nicklas, 'Die "Juden” im Petrusevangelium (PCair 10759): Ein Testfall', NTS 47 (2000) 206-21; A. Kirk, 'The Johannine Jesus in the Gospel of Peter', Jesus in Johannine Tradition (ed. R. F. Fortna and T. Thatcher; Louisville, KY: Westminster John Knox, 2001) 313-21.

59 Matt 27.62: chief priests and Pharisees; cf. John 18.3; Matt. 28.11-12: chief priests and elders.

602.5 and 5.15: 'It is written for them that the sun should not set on one that had been put to death'; cf. Deut 21.22-3. 
Gos. Peter therefore provides a distinct account of the passion and resurrection of Jesus. Striking characteristics include the depiction of the Jews and the detailed description of Jesus' resurrection. Compared to previous versions of the passion events, historical details are fading out. The purpose of this rewriting is to demonstrate Jewish responsibility for the death of Jesus. The Jews must recognise that they have acted against the Scriptures and therefore have done evil to themselves (7.25). Gos. Peter apparently presupposes a separation, even a hostility, between Jews and Christians, and it has therefore been suggested that the text originated in the atmosphere of the Bar Kochba revolt. ${ }^{61}$ This proposal, however, might be too narrow, since an atmosphere of hostility between Jews and Christians can be presupposed at many points in the second century. Moreover, the depiction of the Jews in Gos. Peter can be related to other writings, such as e.g. the Gospel of John, the Apocalypse of Peter and the Gospel of the Saviour. In a situation of mutual hostility, Gos. Peter makes the passion story meaningful for a new context by way of creative reinterpretation.

Gos. Peter can therefore be described as a creative 'recreation' of the Jesus story (or at least of parts of it) from a second-century perspective. ${ }^{62}$ Like Gos. Thom., it is related to earlier Jesus traditions, probably even in written form. These traditions or narratives are reinterpreted from a new perspective. Thereby, the political and religious milieu of the passion events is still recognisable, even if it becomes blurred compared to older presentations of these events. However, Gos. Peter can be regarded as an autonomous version of the passion narrative, demonstrating that these events were regarded as a constitutive part of the Jesus story and therefore presented in a way that makes them meaningful for Christians in a later situation.

\section{Concluding Remarks}

At the beginning of this article it was stated that the memory approach can effectively be applied to Jesus studies on the basis of the hermeneutical insight that the past is always perceived from the perspective of the present. For historical-critical Jesus research, the memory approach therefore brings to awareness the fact that even Jesus portraits with a historical-critical basis are products of historical imagination and therefore subject to correction and revision.

61 Cf. Kirk, 'Johannine Jesus' (n. 58).

62 Cf. A. Kirk, 'Tradition and Memory in the Gospel of Peter', Das Evangelium nach Petrus: Text, Kontexte, Intertexte (ed. T. J. Kraus and T. Nicklas; TU 158; Berlin/New York: de Gruyter, 2007) 135-58. The approach of T. P. Henderson, who regards Gos. Peter as a 'rewritten gospel' compared to the New Testament Gospels, is unsatisfactory since the idea of the 'rewriting' of Scripture is hardly appropriate for second-century Gospels and their relationship to previous Gospels. The contours of the Jesus story in the second century are still fluid and can hardly be grasped within a model of the 'rewriting' of an established framework of Jesus' activity. 
Early Christian memories of Jesus commence with the confession that he was resurrected and exalted to heaven. Based on this belief, his earthly activity was interpreted as the appearance of God's representative who acted in God's spirit and on God's authority. This perspective is presupposed in the narrative accounts of his earthly career in early Gospels. First-century Jesus narratives also show a biographical interest in the figure of Jesus. Accordingly, the early Jesus tradition contains details about the geographical, political and religious setting of his activity. Even if the narrative presentations are based on early Christian confessions as well as on Jewish Scriptures as their area of reference, it remains striking that these early narratives have also preserved details of Jesus' activity in the Jewish environment of first-century Galilee.

In second-century Gospels, the details of the historical setting are reduced in favour of an emphasis on the meaning of Jesus' teaching and the circumstances of his earthly appearance for a later situation. The two examples chosen here, the Gospel of Thomas and the Gospel of Peter, belong among those non-canonical Gospels which have preserved and creatively reinterpreted features of the historical setting of Jesus' activity. The concept of 'memory' as it was described above can therefore be applied - and in fact has been applied - to these Gospels, both of which can be described as memories of Jesus with distinct profiles. ${ }^{63}$ In both of these writings, older traditions and previous narratives of Jesus' teaching and his earthly activity are presupposed and interpreted from a new perspective. Thereby, it was not of primary importance to preserve historical details, but rather to make Jesus' earthly appearance meaningful for later situations. From the perspective of collective or even cultural memory it can be observed that Jesus is portrayed in these writings as the revealer of a knowledge that leads to the 'Kingdom of the Father', or as the 'Lord' and the 'Son of God' who was crucified and who rose again. Both of these writings make use of the early Jesus tradition in quite different ways. They can therefore be described as creative reinterpretations or 'updated re-narrations' of the early Jesus tradition in their respective ways. ${ }^{64}$

The non-canonical Gospels discussed here continue tendencies that can be seen already in earlier narratives. They pursue approaches to interpreting the earthly activity of Jesus from a post-Easter perspective that can be recognised by a comparison of the Gospel of John with the Synoptic Gospels as well as by the addition of the appearance stories in John 21 and the Longer Ending of Mark. The post-Easter perspective in these texts can be perceived in their emphasis on Jesus as a teacher of heavenly wisdom contained in 'hidden

63 Cf. Schröter, 'Erinnerung' (n. 2) for the Gospel of Thomas, and Kirk, 'Tradition and Memory in the Gospel of Peter' (n. 62) for the Gospel of Peter.

64 The expression 'updated re-narration' ('aktualisierende Neuerzählung') was used for the Gospel of Peter by Augustin, Juden (n. 57), 98-108. 
words' and on the extraordinary circumstances of his resurrection. This tendency can also be observed in other writings which present the post-Easter teaching of the resurrected Jesus about the relationship of the upper world to the heavenly realm and the way to salvation as the ascent of the soul. ${ }^{65}$ The non-canonical Gospels are therefore witnesses of a diversity of early Christianity in that they demonstrate that Christ groups in second-century Christianity applied the Jesus tradition in diverse ways and to different social and political situations of Christ-followers or Christian communities. Against this background, the noncanonical Gospels contribute to early Christian memories of Jesus in distinctive ways.

65 Examples are the Gospel of Mark, Apocalypse of John, Epistle to the Apostles and Wisdom of Jesus Christ. 